\title{
Beyond the Verbiage: Consumerism through Tourism and Its Manifestations in Small Islands and Remote Places
}

\author{
Lea Kannar-Lichtenberger ${ }^{\mathrm{i}}$ \\ Sydney College of the Arts, University of Sydney, Lillyfield, Australia
}

Copyright $\bigcirc 2018$ by authors, all rights reserved. Authors agree that this article remains permanently open access under the terms of the Creative Commons Attribution License 4.0 International License

\begin{abstract}
Beyond the Verbiage' are encounters with the environment. So much has been written about our consumerist contemporary society and Climate Change. This paper is an artistic examination of research conducted by Lea Kannar-Lichtenberger, through onsite investigations, spanning a four-year period, of small islands and isolated environments. Chapters will explore research undertaken on Lord Howe Island N.S.W. Australia, Galapagos Islands Ecuador, Faroe Islands the North Sea and Deception Island Antarctica. Through video, sound, and installations these investigations work to create awareness about the impact the international traveller is having globally, but especially in places once deemed only for the experienced intrepid traveller. This paper explores how the consumer is enticed not just by the tourist industries' images, specials and catchy jingles but also via the documentary beautifully edited to capture this planet's extraordinary environment. These inducements create a desire within the viewer to be immersed in these fragile isolated places; however, the resulting manifestation explored here creates a window into the vacationer's impact on the viewed utopian destination. 'Beyond the Verbiage' is just one part of a discourse to increase awareness of how society's seemingly simple actions in travelling potentially have a disastrous 'butterfly effect' on such remote and utopian destinations.
\end{abstract}

Keywords Lord Howe Island, Faroe Islands, Galapagos Islands, Antarctica, Deception Island, Climate Change, Consumerism, Tourism, Anthropocene

\section{Introduction}

'Beyond the Verbiage' are encounters with the environment. Examinations over a 4 year period by artist Lea Kannar-Lichtenberger, that involved onsite research, as the tourist/artist traveller, to small islands and isolated environments.

Through video, sound, and installations these investigations work to create awareness about the impact the international traveller is having globally but especially in places once deemed only for the experienced intrepid traveller. This paper will examine the islands of Lord Howe Island (NSW Australia), 2015 the Galapagos Islands (Ecuador) 2014, Faroe Islands (the North Sea) 2016 and Deception Island (Antarctica) 2017. Examinations will not only explore the impact of the contemporary society through ocean debris on these islands but also the consumer tourist. It will consider what restrictions if any for tourist numbers are in place, the marketing ideology against the current realities and future ramifications of existing best practice.

The pressures from the travel industry to supply the tourist with a more eco-friendly experience have created a move forward, in the protection of the environment. This has some governments closing some regions yearly to tourism, increasing a levy on visiting areas and the development of groups working to help the more environmentally engaged traveller select a journey with stronger eco credentials. Yet without a "universally adopted certification program for ecotourism, tourism operators may market their operations as "ecotourism" while in reality they are "greenwashing... within the tourism industry, ecotourism is the fastest growing sector, growing from 10 to 30 percent a year"[1]. There are arguments to say that by pushing the environmentally focused holiday there is a greater financial gain to providers which ultimately may force changes in best practice, will the need to protect areas for financial gain be the final driving force to save many isolated environments? Many would argue that it is a positive first step and should have a greater focus however in this paper the consumerist as a tourist is examined, how they manifest within the confines of the small islands. The research that underpins this paper is based on a rigor of onsite investigations and so 
it remains limited to only the four visited locations. The Galapagos Islands, Lord Howe Island, Deception Island and the Faroe Islands along with many others are gathering increasing attention for the consumerist travellers' 'bucket list' and it is for this reason that I have remained specific to them.

A deception is being perpetrated on us the consumer, documentaries presented to the unsuspecting viewer come into our homes wanting us to care about the fragile isolated place, however, the resulting manifestation is to create the desire to touch and feel this for ourselves, to consume another utopian destination. Our relationship with Islands has always been one of exploitation and in many cases the depletion of species through unregulated consumption.

Through an interdisciplinary eco-critical vision these explorations are just one small part of a greater discussion of how society's seemingly simple actions in travelling potentially have a disastrous 'butterfly effect' on such remote and utopian destinations.

\section{Lord Howe Island}

(600 nautical miles off the east coast of NSW Australia, examination fourteen days 2014-16)

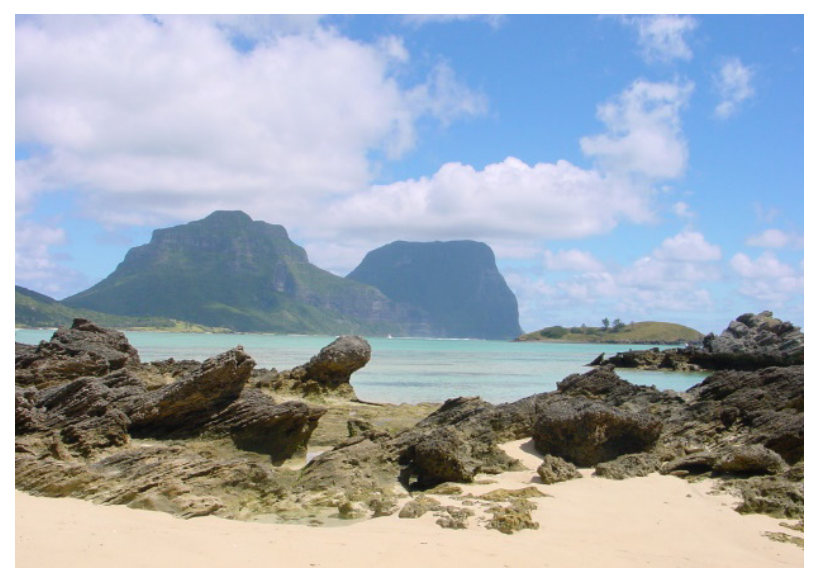

Figure 1. Lord Howe Island

This island sits as a beacon of 'how to' that is, how to control tourism, how to control expansion at any cost, how to exploit it for tourism yet maintain or improve the environmental status quo. In 1982 Lord Howe Island (fig. 1) was inscribed onto the UNESCO World Heritage List, the island board enacted a Regional Action Plan to restrict the island to four hundred tourist beds in 1986[2], then in 1996 N.S.W. Government declared Lord Howe Island a Marine Park.

I have been travelling to Lord Howe Island yearly for the past seventeen years usually for a two week period. During this time subtle changes are observable to the land and on the reef; however, this examination will look at 2015. This island could be seen as exclusive in that only one airline QANTAS has the contract with the Lord Howe Island board for its DASH 8 planes to land, so, therefore, this monopoly keeps airfares high. If you couple this with the bed restriction this creates an ideal holiday destination. There are constant internal and external pressures to change the 'best practice' of what could be seen as an ideal situation.

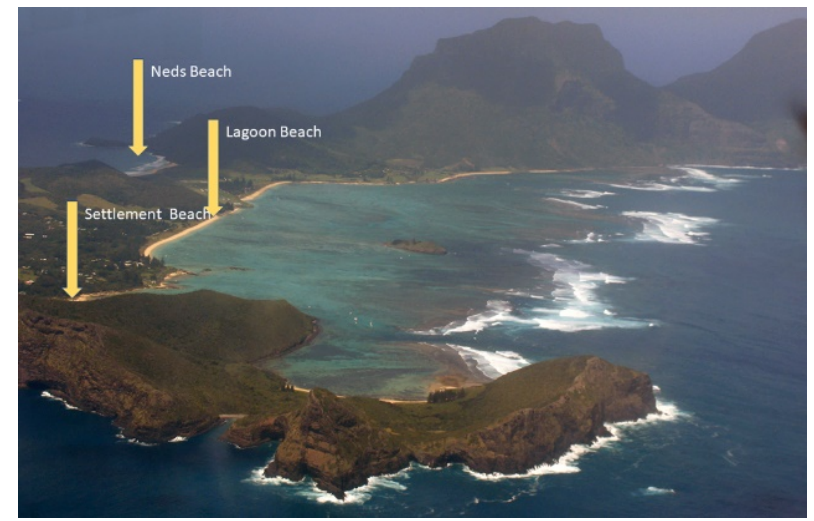

Figure 2. Lord Howe Island Beach Collection Points

In 2015 a collection was made by myself on the three main beaches of Lord Howe Island; Settlement Beach, Lagoon Beach and Neds Beach (fig. 2). This collection comprised of a single walk collecting the flotsam and jetsam of ocean debris above the tide line. There was a distinct difference in the types and quantity of plastics collected between the beaches. With the lagoon/coral reef side of the island comprised of Lagoon Beach and Settlement Beach, the debris collected was sixty-five and seventy pieces respectively. In comparison the ocean facing beach surveyed, without the protection of the lagoon/coral reef, Neds Beach had a total of seven hundred and sixty items of plastic or inorganic materials[3]. This examination explored how the consumerist can impact islands from a distance. This collection was to initiate artworks such as Corpses of the Everyday, 2015 (fig. 3) as a way to bring the awareness of the ocean debris issue into the public arena. This large-scale work reflects the continuous stream of debris that comes in on the tide each day. On a scale, that was until recently, underestimated but one that is currently being discussed in the global arena.

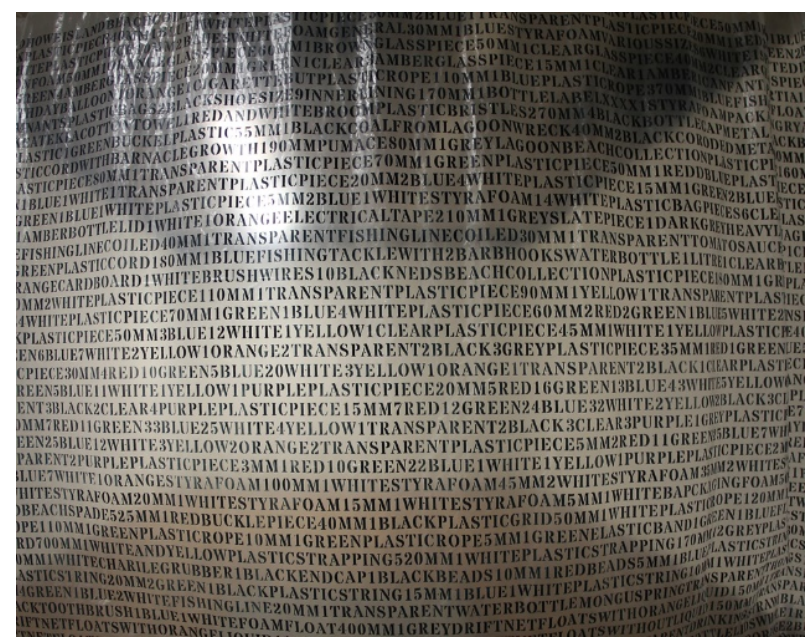

Figure 3. Corpses of the Everyday, 2015 
Boomerang Alliance indicated that current government-sponsored research into the litter that ends up in the Australian oceans is perhaps inadequate "this "badly underestimates" the problem. "Conservatively, we can identify at least 56,000 tonnes of plastic entering our environment every year, [including] beverage litter, tyre dust, synthetic fibres, production waste, microbeads and plastic bags," Boomerang Alliance national policy director Dave West said.'[4]

With the battle just beginning to control and remove what is already in out oceans, there is still a question of how much plastic is being absorbed by the surrounding coral reefs that are not making it onto beaches. Leading one to assume that the microplastics could in effect be trapped in the surrounding reef however the continued breakdown of the larger pieces of plastics may also be causing problems. As they break down in the environment, their binding agents are being dispersed and absorbed by the marine and wildlife that ingests them. Increasingly studies are showing the toxicity associated with this problem[5] on global oceans.

Coral reefs are living entities that around the world are being affected by Climate Change and pressures associated with mass tourism. However, when it comes to the tourist it is easy to be distracted by the larger environmental problems. Yet it is here that the quiet poisoning of global reefs and waters are happening via the use of sunscreens. The average tourist not thinking how the block-out used to protect their skin[6] effects these living spaces. Chemicals used in many sun protection products such as 'Oxybenzone is an emerging contaminant of concern in marine environments' [7] its capacity to affect the Ultra Violet light that damages our skins has now been linked to a toxic effect on the living coral. The coral reef, where humanity can swim above a living entity larger than oneself floating in the life-giving waters of the planet, few if any tour operators on reef systems ask the tourist to refrain from using sunscreens or urinating in the water which releases hormones and acidic toxins onto these filter-feeding microscopic algae zooxanthellae

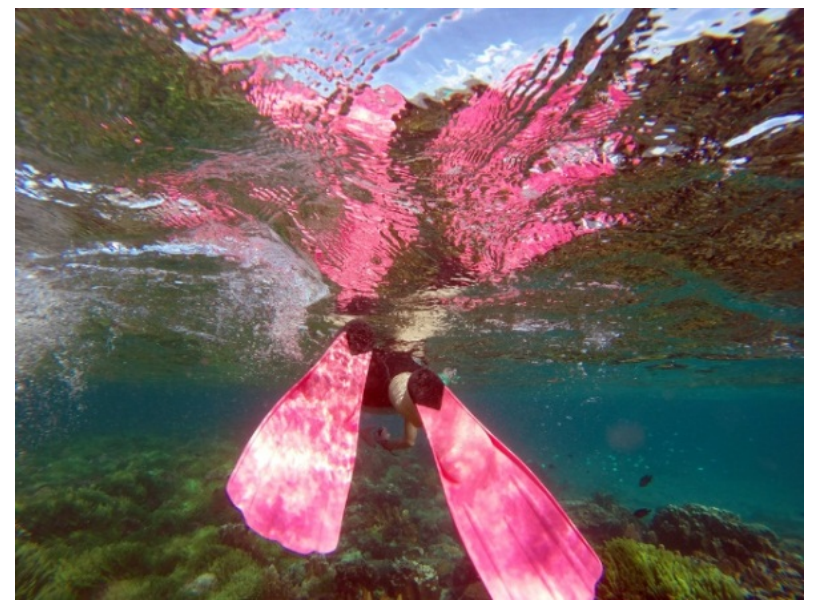

Figure 4. The Reef Flys 2015 ongoing
These issues inspired a photographic series of works titled The Reef Flys 2015 ongoing (fig. 4) as the tourist's presence impacts these places. They spit and piss, moving in packs or solo they swarm over the corals they have come to explore. Advertising from the travel industry to visit this island has its limitations, as prices are high, along with the age demographic of tourists[8] currently visiting Lord Howe Island and strictly adhered to bed numbers will perhaps work in its favour to stay out of the mainstream, and hopefully help it to preserve its unique environment.

\section{Galapagos Islands}

(600 nautical miles of Ecuador, examination fifteen days 2014)

By far the most famous of islands to visit, for islands such as the Galapagos, you find a plethora of advertisements enticing you to venture forth. A verbiage of dialogue confronts and confounds the traveller, rarely, however, is it about the impact they will have by doing this journey, and we are not talking 'carbon footprint'.

The history of visitation to these islands since the Galapagos Archipelago was discovered in 1535, by Fray Tomas de Berlangaby[9] has in the past 70 years an exponential factor. Where once only whalers and passing ships visited to collect supplies it is probably best known as the place Charles Darwin visited in 1835 that lead to his epiphany on natural selection[10]. Darwin noted in his journal the physical differences between island tortoises. He also witnessed the exploitation of this species by the, as then newly established communities and the whaling industry, where the removal and consumption of tortoises from the islands has led to a severe depletion and in some cases extinction[11].

The examination of this Archipelago was undertaken in the same manner as many tourists who travel here on board ship for 15 days 22 locations on 14 Islands, on board one of the many timber sailing sloops that service this industry 'The Cachalote' a vessel designed for a maximum of 16 passengers. This vessel is part of an armada of cruise ships that circle the Galapagos islands carrying between 16 and 100 passengers all being taken to see if this place lives up to our expectations. Whilst almost no manmade ocean debris was visible during this journey you could not say the same for the human tourist impact.

A deception is being perpetrated on us, the consumer, by the tour company with their glossy brochure full of phrases to entice you: 'Spectacular, isolated \& home to the famed Galapagos giant tortoise'[12], 'A naturalist's paradise'[13], 'it's like a nature documentary you can walk through. Get off the couch and come to see it for yourself' [14].

Naturalist presenters such as David Attenborough come into our homes via the documentary wanting us to care about these fragile isolated places. However, the resulting manifestation is to create the desire to touch and feel this for ourselves, to consume another utopian destination. 


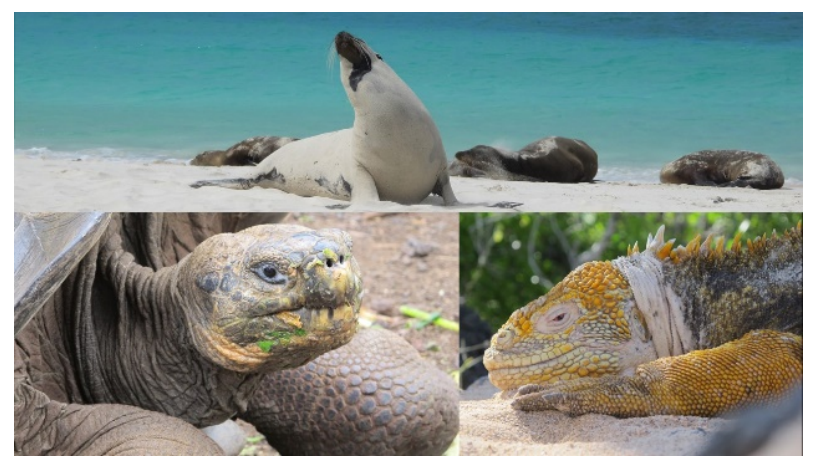

Figure 5. Galapagos Fauna, 2015

The photogenic sea lions sleeping in groups and land iguana awaiting its audience. (fig. 5). The docile animal habitualised to the tourist presence barely reacts to the photograph, except to move away, going about its altered life. This proximity is the encounter is what the visitor craves, thus living up to the hype, but changing their natural behavour to accommodate our presence. The tourist on the other hand excitedly informing our friends of how close we could get posting photos on social media, which increases the desire factor.

On the vast majority of the islands in the Galapagos Archipelago, those you could only reach by boat and importantly further than a day trip outing, superficial observations saw little of how our human presence was affecting the behaviour of wildlife. But closer to town, the places that we have embedded our worlds for the past 250 years it is a story of competition, their lives and ours. I witnessed the wildlife interventions and in their way, performance pieces, that created their own social comment on how much their lives are changing due to our presence. Is this a take back of the land? (fig. 6) How long will it last before the local population no longer tolerate the inconvenience this creates in their human world.

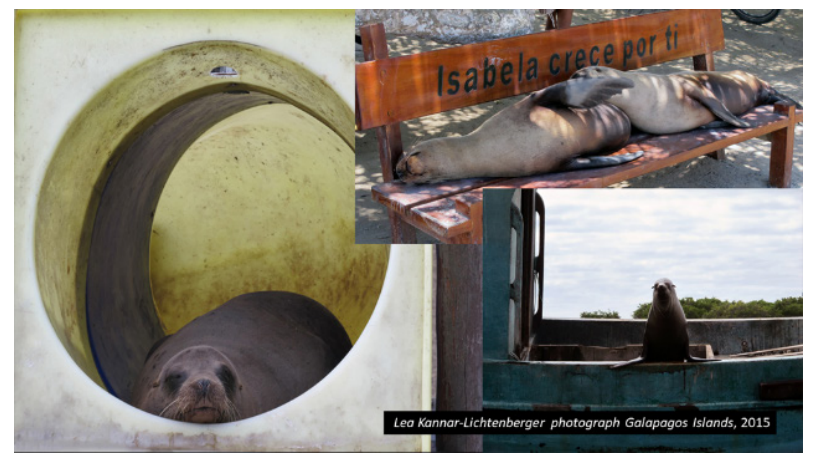

Figure 6. Galapagos Fauna, 2015

In 1960 some one thousand people visited the Galapagos Archipelago; in 1990 forty thousand: then in 2014, two hundred and fifteen thousand six hundred and ninety one people from one hundred and fifty nine counties converged on this world heritage site[15]. My presence like those who travelled with me is creating a spiral of destruction. The local landscape is being destroyed to build more land-based accommodation. Perhaps the greatest impact comes from the lack of fresh water on the islands. This is supplied by modern technology of the desalination plant, supplying not only the people on land but also portable desalination plants on board each touring ship to give us the fresh water we need to survive in this hostile environment. It was more the mobile desalination plants that raised questions for me around the toxic discharge of highly salted effluent on the islands they visit. All the ships must moor in the same place at each island for up to 12 hours at a time. With the industry warnings of the toxicity[16] of this effluent in the creation of dead zones, it raises questions of what impact this discharge will have in the surrounding waters.

As pressure mounts in these islands, the cumulative tourist effect from not only the ships but the increasing land-based accommodation puts pressure on all, from the supplies of food to the essential need for fresh water from the use of desalination plants. Circumventing the governments regulations has seen an increase in the use of a loop-hole of non-permanent structures or 'glamping' land-based accommodation being built adding to the environmental pressures.

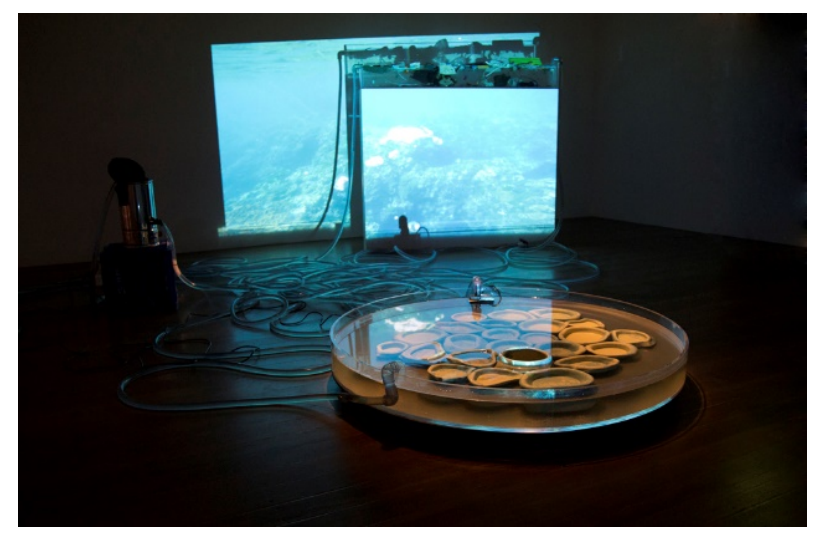

Figure 7. Towards Dystopia, 2015

Towards Dystopia 2015 (fig. 7) is an installation that combines Lord Howe Island with the Galapagos Island both, creating a discourse about the human impact on World Heritage Islands from the desalination and waste, to the macro and micro that affects these places. Whilst the restriction on tourist numbers are in place on both islands, the implementation and adherence to these restrictions appear to the casual observer to be invisible in the Galapagos Islands.

Towards Dystopia 2015 (fig. 7) has at its heart a large-scale Petri dish. This works as a comment on the connections to science and how it is working for (eg. looking for ways to save non-human life and deal with Climate Change etc) and against (eg. the creation of more disposable technology and plastics etc) the preservation of the marine environment. Inside the dish are ceramics, glazed the colour of the ocean and covered with a list of all the plastic debris that has been collected in single walks on 3 separate beaches on Lord Howe Island, giving a voice to 
the microplastics that are being absorbed by the reefs. In this installation, the collected debris from Lord Howe Island floats in the fish tank which acts like a snapshot of our impact in the oceans.

\section{The Faroe Islands}

(The North Sea a protectorate of Denmark, examination twenty six days 2016)

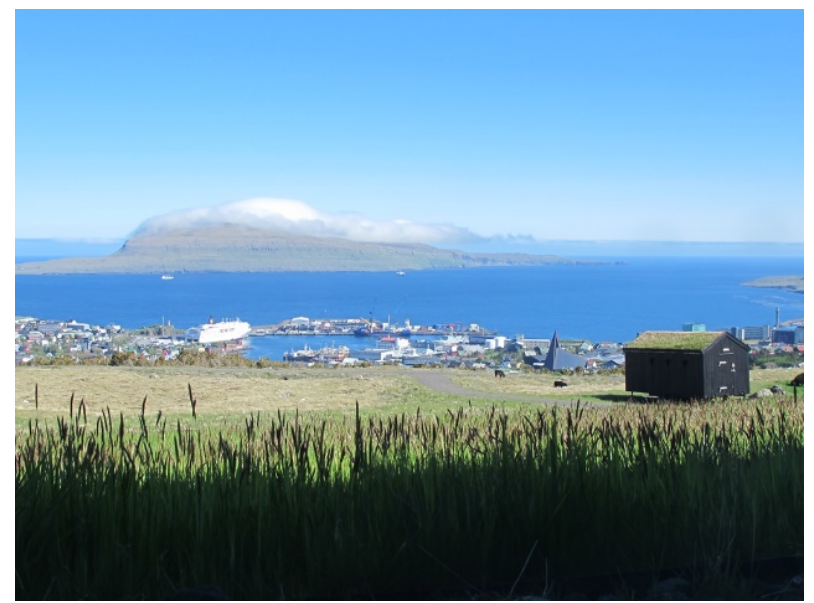

Figure 8. Torshavn capital of the Faroe Islands, 2016

In the middle of the North Sea, you will find the Faroe Islands (fig. 8). My journey here was partially as a backpacker and partially aboard the Johanna (out of Vagur of Suduroy)

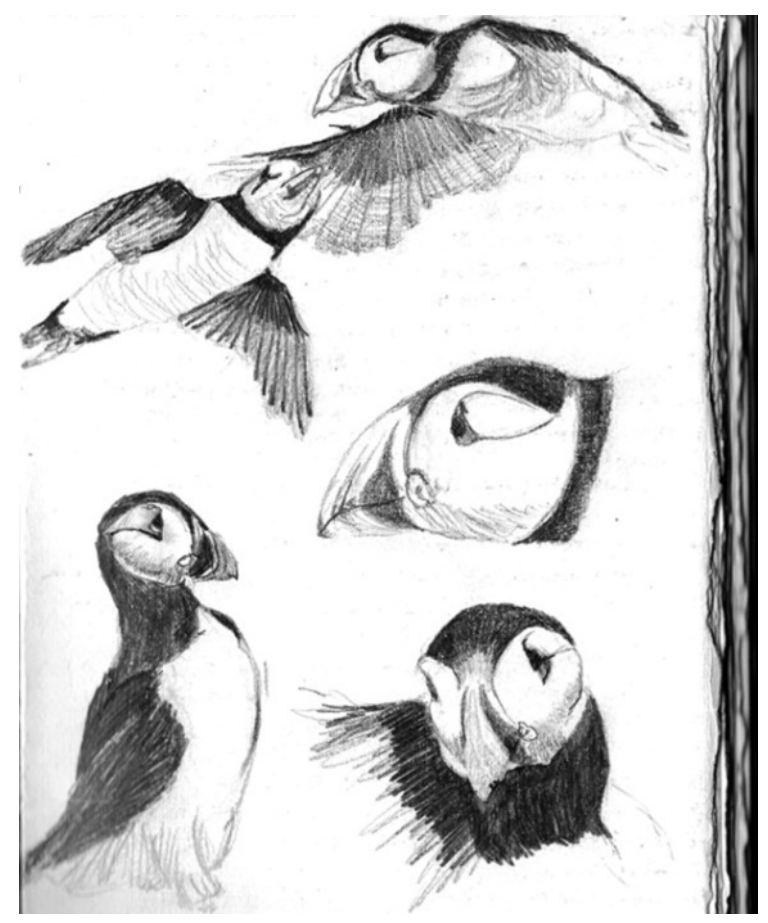

Figure 9. Puffin drawings by Lea Kannar-Lichtenberger, 2016
With a small population of forty eight thousand eight hundred and sixteen, the influx of tourists during the summer months is significantly felt. 2015 saw forty thousand seven hundred and ninety eight which grew exponentially in 2017 to an astonishing three hundred thousand through the airport alone[17]. A once small subsitance farming community are fledglings in the world of the ecotourist and this onslaught will have huge effects not only on increased infrastructure but the impact to the fragile wildlife. 'Once you find an attraction and people want to come, then you are really opening up an area for mass marketing tourism'[18]

One such that will feel the pressure is the Puffin (fig. 9), that very cute bird that seems to be a cross between a penguin and a bird is one of the biggest attractions in the Faroe Islands. I question now about how to be sustainable with increasing visitors during the summer breading season going to the Mykines all with one quest... to see the puffin, the nesting Gannet and to plant their flag, so to speak by way of the selfie, at the lighthouse. But at what cost?

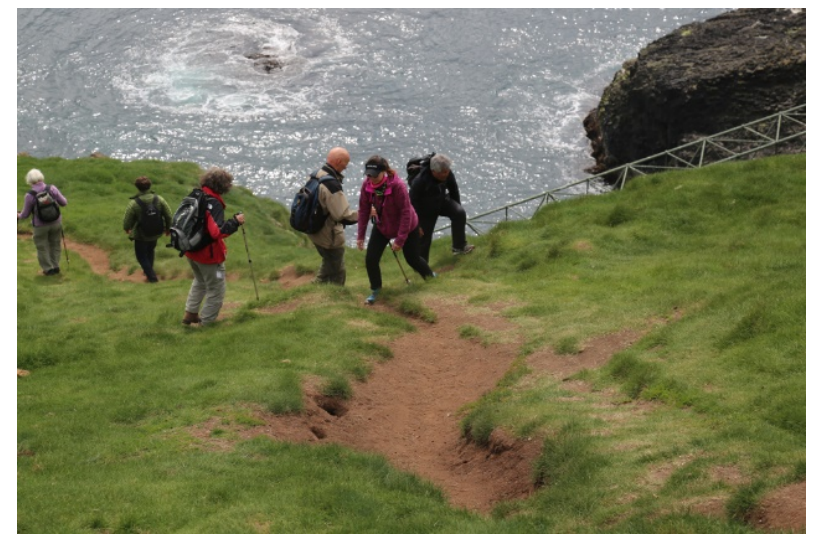

Figure 10. Tourist walking trail Mykines Puffin colony, 2016

With only two islands left with significant Puffin nesting populations, there appears to be no real control of the tourist. With every step, the tourist is contributing to the struggle this ground breeding bird has. To visit the last island in the Mykines the tourist has to walk in pathways that cross the nesting places of this bird. Every footfall off the path and even on the path in some places run the risk of collapsing a nesting burrow (fig. 10).

Historically the Faroe's once had five islands of Puffins nesting and breeding, human interference from the introduction of rats and human consumption[19] has now reduced this to two islands. In 2016 the tourist management appeared to fall sadly behind, one hopes this will change in the future and perhaps with only six permanent residents on the island perhaps now the locals can stop eating them.

Not only will the impact from the 2017 tourist figures[20] all over these islands be massive but the ocean debris was astonishing (fig. 11) in a place that has such limited habitation. Isolated beaches such as Hvalba came alive with the breeze as single beads of Styrofoam danced on the 
air currents which only adds to the issues facing these islands.

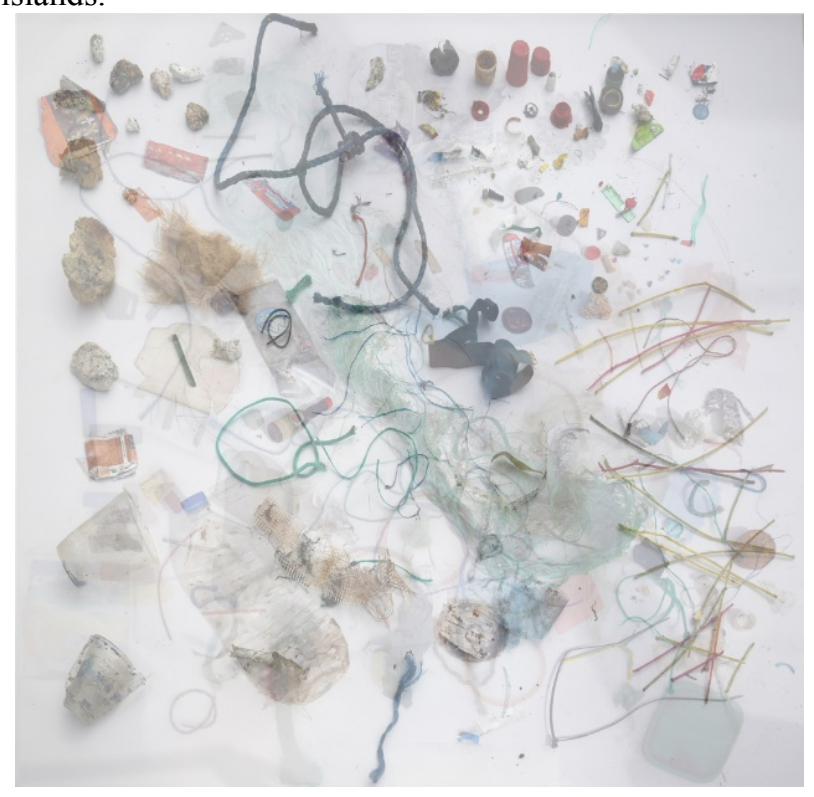

Figure 11. From us to you - Faroes, 2017

\section{Deception Island}

(South Shetlands Islands off Antarctica, examination nineteen days 2017).

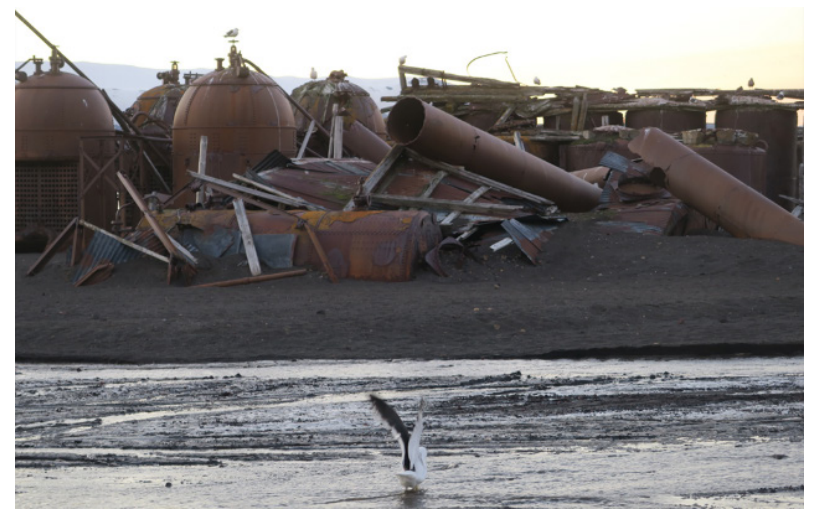

Figure 12. Deception Island abandoned whaling \& research station, 2017

This active volcanic island is the first port of call for many of the cruise ships heading into Antarctica. With 57\% of its total land mass glaciers, it stands to be impacted upon by significantly by climate change and glacial melting.

Deception Island with its abandoned $20^{\text {th }}$ Century industrial debris, a remnant from both the whaling industry and a British Research Station (fig. 12) a reminder of how little money is being spent in the removal of rubbish from the Antarctic Territories. Deception Island and specifically the whaling station is sold to the tourist as the "\#4 of 13 things to do in Antarctica'[21]. The abandoned station sits as a beacon of our interference on this landscape, standing in the shadows of this debris on such a large scale you recognise that the cost of restoration of this site would have a huge price tag and instead, it is sold as a tourist destination. Walking around the station, stepping next to the bleached remains of whales long since forgotten and the processed blubber that still leaches from the soil as it mixes with the increasing runoff from the glacial melt, you cannot help but be moved.

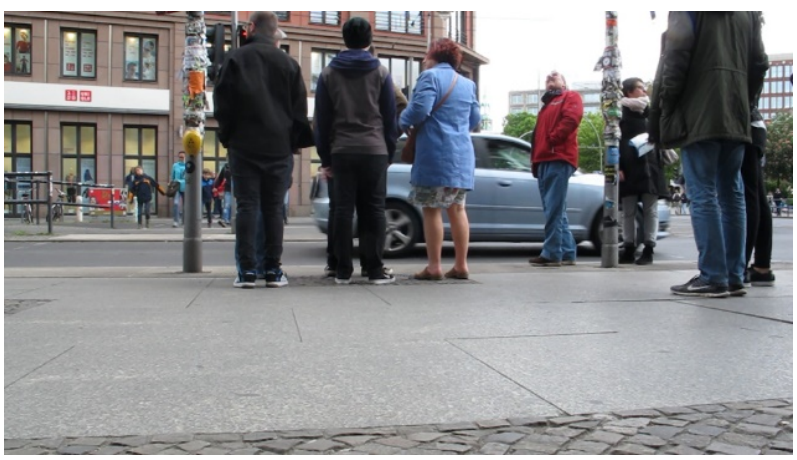

Figure 13. Alexanderplatz, Berlin 2016

However, my journey to this place was to create a new work. One that would take the message of what is happening to the glaciers in Antarctica and bring the viewer closer to the realities of our modernity. Deception I Berlin 2017 (fig. 14) With its inception on the streets of Europe with the collection of videos from street corners from places such as Berlin (fig. 13) and Edinburgh. These street videos where then projected onto a melting glacier on Deception Island (fig. 14), with the resulting projection recorded to create a new installation. The images from the streets of Berlin loop on a 1 min repetition, a loop of video that speaks to the banality and repetition of our daily lives but the sounds extends to a 3 min cycle when the process of repetition begins again. Deception I Berlin 2017 (fig. 14) creates a tension of space and time that drives these elements together with a heartbeat of place and connection.

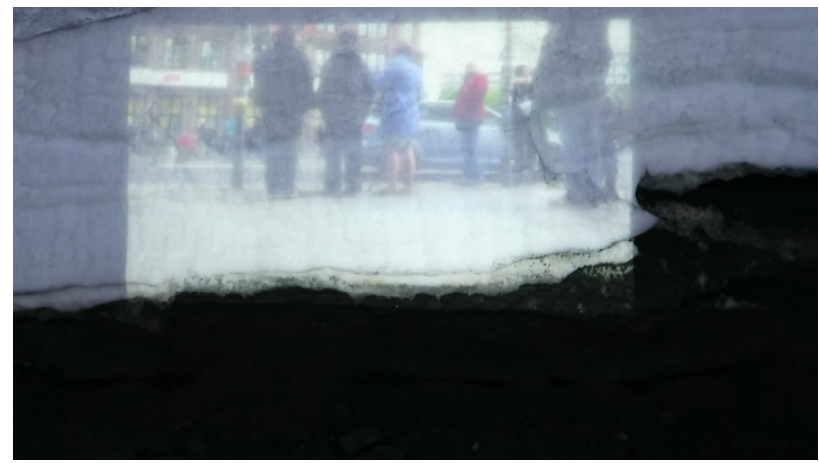

Figure 14. Deception I Berlin 2017

This work created on Deception Island is about deception, not just the name of the place but of the way we as a society use deception to not see what we know to be true. The deception of our governments in not taking strong and immediate action. The deception of the oil industry in working to create atrophy about the larger picture of its 
practices. Deception is just one part of a dialogue a discussion, to create further awareness around how society's actions have a 'butterfly effect' on such a remote, utopian destination. A place that one would have thought unaffected by our society but through this work, I show how we are effecting and affecting Deception Island, which by its isolation, its surrounding waters, it and its wildlife remain virtually invisible to our world.

I have concerns about the future of the places in Antarctica as the pressure from private enterprise and the tourist dollar pushes more ships to take passengers for their 'Antarctic Experience'. There appears to be no overseeing government or body that controls the numbers of tourists that visit here. In my experience, if you have a vessel which ticks all the safety requirements and an experienced captain (regardless of any Antarctic experience) then you can head south. With anecdotal conversations with biologists on the Spanish station indicating that there is has been a significant fall in penguin numbers over the past 20 years then increased tourism can only add to the pressures of the wildlife.

In a recent interview with Emily Lo, Store Manager for STA (Start The Adventure) travel agents based at University of NSW, Emily indicated "what the student body wants from their travel experience has changed. They no longer want the altruistic holiday where the culture of the visited place was paramount. Now they want the 'selfie' experience where they can travel and collect the same shots already posted on Instagram and other social media networks"[22]

This past summer 2017 -18 some 51,000[23] tourists visited this remote place, and with vessels such as the Azamar Pursuit heading to Antarctica carrying 690 passengers[24] and a new generation of luxury expedition vessels carrying helicopters, submersibles, and advanced scuba-diving equipment the glimpse into the expansion of Antarctica as a consumerist commodity has already begun.

\section{Conclusions}

These islands are just a few among many that are gathering increasing interest for the consumerist travellers' 'bucket list'. How governments handle the pressure of tourist needs, private enterprise and environmental protection are yet to be seen. Many countries are in a better position for governments to pass (and enforce) legislation to isolate areas of environmental significance. However small islands face increasing pressure for external access as more often than not there is a reliance on the tourist industry for financial independence and support. Therefore, isolating for environmental protection has greater ramifications on island populations with few taking the path like Lord Howe Island to restrict numbers of tourists visiting their shores. What restrictions that may be in place are either circumvented by locals for profit, as seen in the
Galapagos Islands, or under pressure from the tourist industry to relax control.

Robert Fletcher in Contradictions in Tourism writes, "the rise of "new" or "alternative" tourism offering a variety of flexible, individually tailored trips concurrent with capitalism's shift' has driven 'commodification and trading new forms of "natural capital"; replacing state control of resources with capitalist markets' [25]. Whilst there is a drive to protect the unique iconic spaces for the future it needs to be in an altruistic manner. If we have learned anything from places like the Galapagos and Faroes Islands is that what follows is not about looking after the environment but the money made from the exploitation here.

Ultimately it appears that social media will be changing how the next generation impact on the places they visit. As tourists, we rarely notice how much we affect these spaces or we choose not to see. What I have discovered is the exponential increase in tourist numbers that are affecting our so-called 'Pristine or Natural' places. These places, going forward, are being shaped by an online and media culture. One hopes that significant government intervention happens sooner rather than later to maintain a strong environmental balance.

\section{Acknowledgements}

The research on the Galapagos Islands was supported by; the University of Sydney, Sydney College of the Arts PRSS (Postgraduate Research Support Scheme) Grant program 2015 and Professor Emeritus Helen Tiffin

All other research was self-funded. Journeys to The Faroe Islands and Deception Island were with Not for Profit organisation The Ninth Wave.

\section{REFERENCES}

[1] Robin M Self, Donald R Self, and Janel Bell-Haynes, "Marketing Tourism in the Galapagos Islands: Ecotourism or Greenwashing?," International Business \& Economics Research Journal (IBER) 9, no. 6 (2010)

[2] NSW Government, "Lord Howe Island Regional Environmental Plan 1986," ed. Parliamentary Counsel's Office (NSW Parliment Gazette1986-013).

[3] Lea Kannar-Lichtenberger, "Beach Collection of Ocean Debris - Lord Howe Island," (2015).

[4] Lucy Cormack, "Marine Plastic Pollution Senate Inquiry Targets Australian Ocean Pollution," Sydney Morning Herald 2016.

[5] Kosuke Tanaka et al., "Accumulation of Plastic-Derived Chemicals in Tissues of Seabirds Ingesting Marine Plastics," Marine pollution bulletin 69, no. 1 (2013).

[6] Mirabelle M. P. Tsui et al., "Occurrence, Distribution, and 
Fate of Organic Uv Filters in Coral Communities," Environmental Science \& Technology 51, no. 8 (2017).

[7] Downs C.A. et al., "Toxicopathological Effects of the Sunscreen Uv Filter, Oxybenzone (Benzophenone-3), on Coral Planulae and Cultured Primary Cells and Its Environmental Contamination in Hawaii and the U.S. Virgin Islands," Archives of Environmental Contamination and Toxicology 70, no. 2 (2016).

[8] NSW Government, "Lord Howe Island Visitor Survey," (Destination NSW, 2017).

[9] Michael Hume Jackson, Galápagos, a Natural History, 5 ed. (Canada: University of Calgary press, 1993), Natural History.

[10] Charles Darwin, 1809-1882, On the Origin of Species by Means of Natural Selection, Rev. ed. ed. (Mineola, New York: Dover Publications, Inc, 2006).

[11] Anon, "Giant Tortoise Restoration Initiative," http://www.galapagos.org/conservation/tortoise-restoration l.

[12] Intrepid Travel, "Galapagos Islands," https://www.intrepidtravel.com/au/galapagos-islands.

[13] G Adventures, "Galapagos Cruises," https://www.gadventures.com.au/travel-styles/cruising/gal apagos/.

[14] Ibid.

[15] Galapagos Conservancy, "Galapagos Tourism Increased 6\% During 2015," (2015), http://www.galapagos.org/newsroom/2014-tourism-report/.
[16] Lenntech B.V, "Reverse Osmosis Desalination: Brine Disposal," (Lenntech2015).

[17] Vagar Airport, "Over 300.000 Passengers at Faroe Islands Airport for the First Time," FAE Vaga Floghavn, http://www.fae.fo/en/about-vagar-airport/news/over-300-0 00-passengers-at-faroe-islands-airport-for-the-first-time/.

[18] Robin M Self, Donald R Self, and Janel Bell-Haynes, "Marketing Tourism in the Galapagos Islands: Ecotourism or Greenwashing?," International Business \& Economics Research Journal (IBER) 9, no. 6 (2010).

[19] Jens-Kjeld Jensen, Hnj's Indispensable Guide to the Faroe Islands - Breeding Birds of the Faroes (H.N. Jacobsens Bokahandil, 2008). (Adamson, 2005)

[20] Airport, "Over 300.000 Passengers at Faroe Islands Airport for the First Time"; ibid.

[21] Various, "Deception Island - \#4 of 13 Things to Do in Antarctic Peninsula," Tripadvisor Australia, https://www.tripadvisor.com.au/Attraction Review-g6601 83-d8050891-Reviews-Deception_Island-Äntarctic_Penins ula.html.

[22] Emily Lo, interview by Lea Kannar-Lichtenberger, 2018.

[23] Unknown, "No Freeze on Number of Tourists Visiting Antarctica," May 2, 20182018.

[24] [24] Brian Johnston, "Small Ships, Big Ambitions," The Sydney Morning Herald, April 7, 20182018.

[25] [25] Robert Fletcher, Katja Neves, "Contradictions in Tourism: The Promise and Pitfalls of Ecotourism as a Manifold Capitalist Fix," Environment and Society: Advances in Research, 3 no 1 (2012)

i Lea Kannar-Lichtenberger, MA, MFA, (Sydney College of the Arts) is an artist exploring the connections between science and art. Focusing on the impact of contemporary society, through tourism on sensitive ecosystems and island communities via immersive residencies or eco-tourism. Lea's artworks were recently shown at the Jane Goodall Foundation Symposium Brussels, Stunning Edge Exhibition Taiwan, the New York Hall of Science, Harbour Sculpture Sydney, Waterhouse Natural Science Art Prize and in her recent solo exhibition 'Distorted Truths' - Spectrum E.C.U., W.A. Since 2014 Lea has been delivering lectures and papers that relate to her research and resulting artworks at conferences including; 2014 S.L.S.A., A.N.U., Canberra Australia; 2015 A.E.S.S. at U.C.S.D. San Diego C.A.; 2016 Spektrum (in association with Art Laboratory) Berlin; I.S.E.A.H.K.2016, Hong Kong; Arts in Society Conferences 2016 at U.C.L.A. and 2017 American University Paris; 2017 I.S.A.C.S. 17 Karlsruhe Germany; Sustaining the Seas at S.E.I. Sydney; 2018 Q.C.A. Brisbane Australia and A.A.A.N.Z. Melbourne Australia. 